\title{
Variability in pottery firing technology: choice or technical de- velopment?
}

\author{
Meng Guo* \\ * School of Cultural Heritage, Northwest University. Xi'an, \\ Shaanxi 710069.Email: dreami@126.com.
}

Keywords: Bonfire firing (technique); firing (ceramics); kiln firing; pottery craft; selections and developments.

\begin{abstract}
It was generally considered that it is a technological advancement from bonfire firing to kiln firing. In fact, both of the firing methods possess certain advantages as well as disadvantages. To a specific community, firing technique is a technological choice rather than an outcome of technological development. The technological choices should correspond to the local environments, social contexts, and cultural traditions. Bonfire firing evidences are found in northern and southern China. However, issues of the specific bonfire firing technology as well as the relationship between bonfire firing and kiln firing in both regions need further studies.
\end{abstract}

\section{A brief introduction on the research issue}

The often-heard statement that ceramics are fired in kilns is not entirely wrong but not completely correct either because it ignores the existence of other firing techniques. In his paper on the pottery-making methods of the Va People in Yunnan Province published in 1958, Professor Li provides a detailed description of the special firing techniques used by the Va people in Ximeng 西盟 County, Yunnan. Before firing the pottery, they first carry the dried wares one by one to the firing site, stacking small and large ones together without particular order, and then they bring two bundles of firewood, arranging them around the vessels and placing some on the top as well. Then they use grass as kindle to start the fire. Afterward, the main potter goes off and does other things, but he leaves one of the children of the family to look after the fire. Everybody assembles breakfast and when breakfast is finished, the fire has already burned itself out. At that point, the potter brings a wooden stick to lift the pots one by one from the ashes.

Since these observations were published, this technique of firing pottery by piling it up directly on the ground has entered the conceptual world of the archaeologists, and it has been generally recognized that pottery can be fired without a kiln. In subsequent ethnoarchaeological surveys, it was found that the Dai (Wang 2003), Li, Tibetan (Qimed 1999), $\mathrm{Nu}, \mathrm{Yi}$, and other groups living in high-altitude environments produce pottery without the benefit of kilns. These techniques are summarily referred to as non-kiln firing (bonfire firing), and they all have in common that there is no kiln or other permanent firing structure.

As increasingly more ethnoarchaeological material on ceramic firing techniques became available, scholars have noticed that non-kiln firing is not one unified process but that there are various techniques such as "groundlevel pile firing", "pile-firing in pits", "single-use clayshell ovens" and other methods that differ markedly in construction technique, structure, fuel choice, and firing process, even though they all share the lack of permanent structures.

Archaeological evidence shows that during the Yangshao Age there were already well-constructed pottery kilns, so why do some people still use more "primitive" firing techniques at the present day, 6000 years after Yangshao? By discussing in detail the advantages and disadvantages of kiln firing and bonfire firing, the author of this paper will suggest an answer to this question. By discussing various types of archaeological evidence for kiln-free firing methods, the author will also outline the relationship between non-kiln firing (as represented by ground-level pile firing) and kiln firing.

Variability in ceramic firing techniques and their development routes

Not long after the publication of Professor Li's report, Mr. Lin conducted a survey on pottery-making technology of the Dai people in Jinghong Prefecture, Yunnan, discovering that the Dai people of Manle Village used a different kind of firing technique. "After piling up the wares, straws are spread on all sides of the wares, as well as on top, and then they fully cover the unfired earthen wares, making it into a covered 'straw pile' in the shape of a truncated pyramid, which they coat thickly with a paste made of sand and water. Only then do they light the fire." The author calls this the "closed-fuel" firing method (Lin 1965).

Later, ethnoarchaeological surveys also discovered various other pottery firing techniques. In 1977 and 1982, the Chinese Ceramic Society established a survey team consisting of experts in archaeology, ceramics, and photography that went to the settlements of the Dai and Va peoples in Xishuangbanna Prefecture and Ximeng County, Yunnan Province to conduct ethnoarchaeological research on ceramic production. These two surveys observed three types of firing: above-ground open firing, single-use clayshell kilns, and vertical pit kilns. Among them, the Dai people of Mandou Village used "single-use clay-shell kilns" or what Lin called the "closed fuel" firing method. The single-use clay-shell kiln-firing method is largely 
identical with the open-air pile-firing method with the only difference that a thick layer of plaster is used to cover the straw piled on top of the wares, with the plaster layer being transformed into a clay shell under the influence of the heat of the firing process, helping to trap the heat.

With the continuous collection of ethnoarchaeological evidence from China, it has become clear that non-kiln firing comprises a complex and diverse range of different techniques. In terms of structure and building materials, there are far more than only the two types of open-air firing and thin-shell ovens. For instance, there are also the Tibetan "elevated open-air pile firing", "wall-corner kiln", and "shallow-pit firing" which are all types of non-kiln firing (see Figure 1, quoted from Qimed 1999).

The so-called "elevated open-air pile firing" is similar to the open-air pile firing except for the $2-4 \mathrm{~m}$ high platform on which wares to be fired and fuel are placed, the elevated location providing better ventilation. Even though corner kilns and vertical-pit kilns carry the word "kiln" in their name, fuel and wares are still stacked together to be fired in a process quite different from a real pottery kiln. As the name suggests, wall-corner kilns have the wares and fuel leaning against a wall for firing. Vertical-pit kiln is a firing method in which wares and fuel are placed together into a pit for firing. In this case, the pit is a more permanent structure that is used multiple times, but the structure does not separate fuel and wares, so they are not pottery kilns in the true sense of the word.

Non-kiln firing methods are in no way a prerogative of Chinese ethnic minorities; in the Americas as well

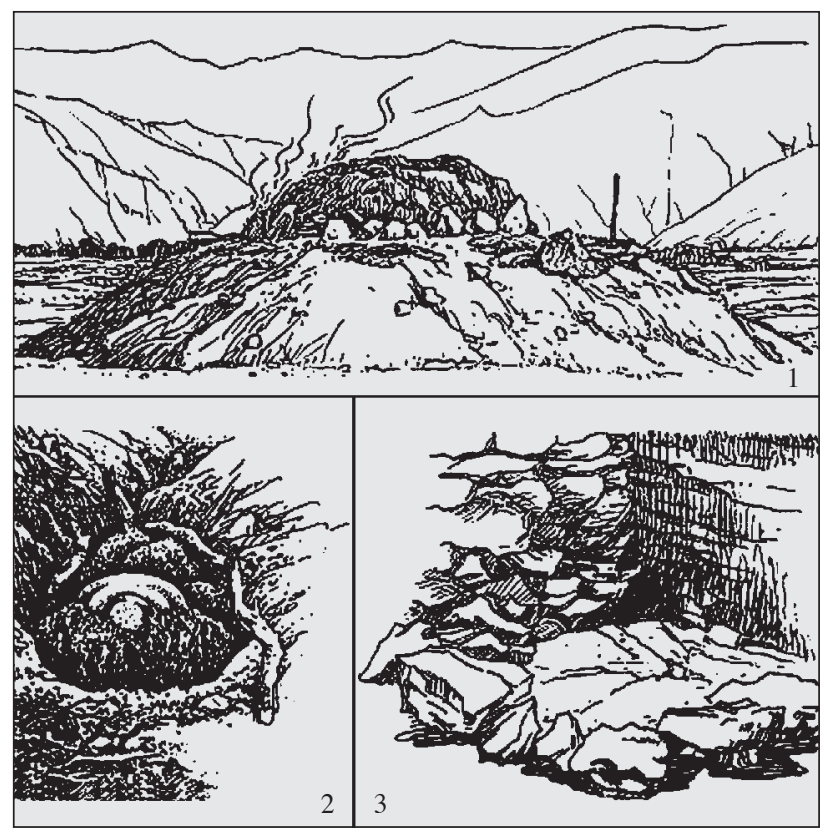

Figure 1 Various types of non-kiln firing in Tibet.

1. Open-air platform firing at Tagba Village in Maizhokunggar County; 2. Vertical-pit-firing in Baxoi County; 3. Wall-corner kiln at Zilung Village in Nang County. as India, Pakistan, Papua New Guinea, and many other places all over the world people have used them in the past and continue a wide variety of different non-kiln firing methods to the present day. For instance, the precontact civilizations in Central America largely lacked pottery kilns, and the residents of Ejulat in Oaxaca, Mexico used a shell-oven firing method that used a shallow pit instead of firing directly on the ground. In terms of materials, some groups used potsherds, stones, wet turf, or cow dung to cover fuel and objects, and all of these structures may be counted under the shell-oven category.

From 1990 to 1992, the University of Brussels carried out "The Ceramics and Society Project" that comprised a survey of the multitude of ceramic firing traditions in Africa. Based on the presence/absence of a pit, its depth, and the presence/absence of an insulating layer (usually potsherds or a metal basin) between fuel and firing goods, the researchers distinguished between nine types of firing technologies: bonfire, surrounded bonfire, bonfire with fireproof materials separating the pots from the fuel, elevated bonfire, shallow-pit firing, pit-firing, pit with fireproof materials separating the pots from the fuel, oven, and updraft kiln (see Figure 2), the first eight of which are not real pottery kilns. In later publications, they redefined them into the following eight types: bonfire, bonfire with light insulation, bonfire with heavy insulation, depression, depression with heavy insulation, pit-firing, pit-firing with heavy insulation, updraft kiln without firebox, and updraft kiln with firebox.

What are the differences in performance among these different non-kiln arrangements? What is the relationship between them? Chinese scholars usually hold that compared to bonfires, shell ovens are more advanced because with the help of the clay layer and the number of holes in it and their locations, it becomes possible to control the temperature to a certain extent; according to this line of argument, bonfire, shell oven, and vertical-pit kiln represent three steps in the development of potteryfiring technologies that occur in chronological order.

Based on his own ethnoarchaeological research and archaeological material, Professor Li (1958) proposed that in China, pottery-making technology developed from "open-air bonfire" to "objects and fuel covered with a layer of clay", to "two fire tunnels on a platform", and finally to "kiln firing".

The above-mentioned theory of the development of ceramic technology has far-reaching influence on the researches on early pottery. In subsequent ethnographic survey reports, the developmental sequence of bonfire firing - single-use shell-oven firing - kiln firing is regularly used to interpret and classify the observations on firing technology made during those surveys. The typical narrative goes as follows: bonfire firing is a more primitive technology than shell-oven firing, showing that it is an earlier stage in the development of ceramic technology while full-fledged ceramic kilns are the most developed technology, representing a late state in 
the development of ceramic firing technology.

It is not difficult to discover that this model for the evolution of ceramic firing technologies is mainly based on ethnoarchaeological materials; in research on pure archaeological materials, there is little work on bonfire or clay-shell ovens. As the earliest pottery wares found in archaeological excavations usually do not occur together with pottery kilns, referring to the ethnoarchaeological evidence on bonfire technology, scholars generally agree that before the invention of ceramic kilns there was a stage at which bonfires were used to fire pottery.

Relying on ethnoarchaeological survey observations from Africa, the author of this paper argues that kiln-free firing techniques are more complex and diverse than the archaeological record suggests. So, is the single developmental sequence of bonfire firing - clay-shell oven firing - ceramic kiln firing really tenable? Where to platform bonfire firing and pit firing fit into that sequence? As

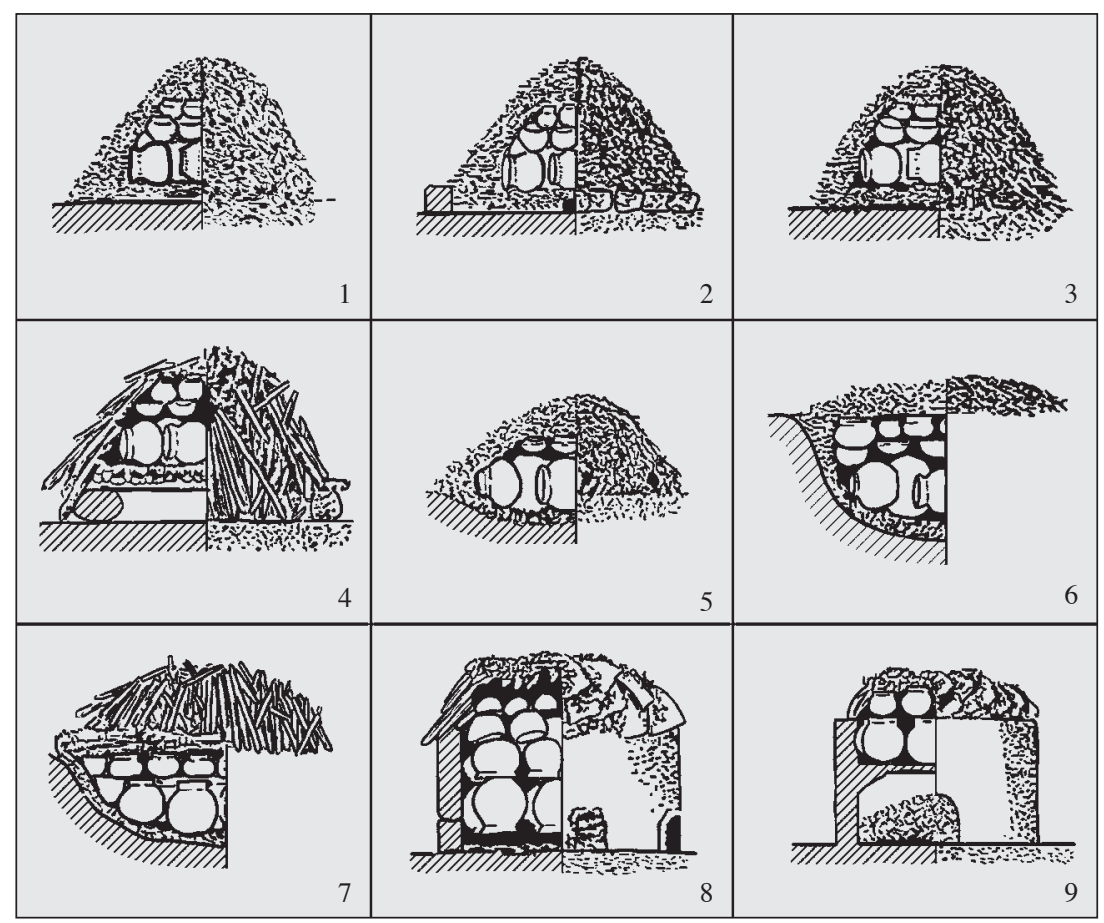

Figure 2 Pottery firing techniques in Africa.

1. Bonfire; 2. Surrounded bonfire; 3. Bonfire with fireproof materials separating the pots from the fuel; 4 . Elevated bonfire; 5 . Depression; 6 . Pit; 7. Pit with fireproof materials separating the pots from the fuel; 8 . Oven; 9. Updraft kiln (Quoted from Gosselain 1995:153, Figure 4). some people may have noticed before, this developmental sequence is based on logical inference rather than actual archaeological evidence. The theoretical basis is that ceramic kilns are more economical and thus advanced in structure and superior to bonfires in many ways, while clay-shell structures are in between the two in terms of structure and performance.

\section{Characteristics of kiln-free firing and kiln firing}

Pottery kilns and bonfires are fundamentally different in structure. First of all, open-air firing structures lack an insulation layer and even the clay layer of clay-shell ovens is very limited in its heat-preserving effects, while the structure of full-fledged pottery kilns provides temperature insulation and traps the heat inside. Secondly, the main particularity of pottery kilns is the spatial separation of firing chamber and stacking chamber. Both characteristics have a positive effect on the performance of the kiln in firing pottery. More specifically, ceramic kilns can meet three major requirements of potters: controlling the firing atmosphere and temperature better, attaining higher temperatures, and improving fuel efficiency.

Whether it is built of adobe bricks or directly cut into a cliff or the ground, these insulating layers are effective at helping the kiln to preserve heat. The kiln structure itself helps the potter to control the temperature and enables them to reach higher temperatures. In contrast, bonfires have only a thin layer of fuel covering the overall structure and keeping in the heat, and as soon as the combustion process begins, this insulating layer is soon burnt up. The insulation performance of clay-shell structures is rather limited as well. Based on his own as well as Shepard's and Rye's ethnoarchaeological research on ceramic production in Cameroon, Congo, Namibia, Egypt, Sudan, India, and Mexico, Gosselain compared five types of firing structures (open firing, open firing with potsherds covering the pots, pit firing, pit firing with potsherds covering the pots, and updraft kiln firing), showing that without a kiln, no temperatures above $900{ }^{\circ} \mathrm{C}$ can be reached and mostly the temperatures reach around $700-800{ }^{\circ} \mathrm{C}$ (Figure 3). There are also reports that with certain kinds of fuel and ventilating conditions, temperatures of $920^{\circ} \mathrm{C}$ or $940{ }^{\circ} \mathrm{C}$ can be reached, but this is rare, and without a kiln it is definitely impossible to reach temperatures over $1000^{\circ} \mathrm{C}$.

The benefit of a pottery kiln is not limited to raising the temperature, but the separation of firing chamber and stacking chamber the impact of the local environment is diminished and the fire can burn more evenly. In contrast, in the case of kiln-free firing there is a constant risk of shifts in temperature, and if the water has not fully evaporated from the wares prior to firing or there is not enough protection during the cooling phase, the ceramics are at risk. Based on survey results, the increase in temperature in case of an updraft kilns is less than $10^{\circ} \mathrm{C}$ per minute while in non-kiln arrangements 


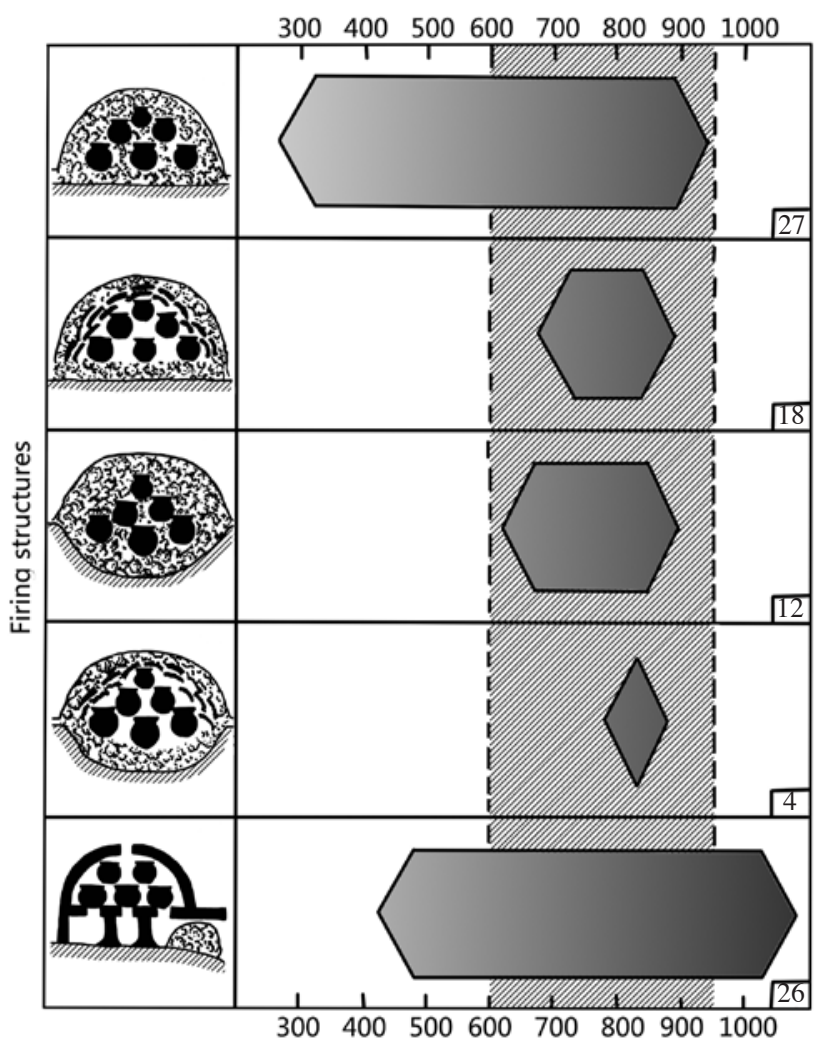

Temperatures recorded $\left({ }^{\circ} \mathrm{C}\right)$

Figure 3 Temperature ranges for the five kinds of firing.

1. Open firing; 2. Open firing with potsherds covering the pots; 3 . Pit firing; 4. Pit firing with potsherds covering the pots; 5. Updraft kiln firing (Quoted from Gosselain 1992:246).

the temperature can rise by $20-40^{\circ} \mathrm{C}$ per minute. If the initial heating occurs too fast, the remaining water in the clay body will be instantly converted into steam and the resultant pressure can lead to cracking.

Another particularity of ceramic kilns is the spatial separation between the firing chamber and the stacking chamber and thus between the wares to be fired and the fuel so the two have not to be piled up together, thus avoiding stains on the surface of the pottery due to direct contact with the fuel; the color of the pottery thus comes out more uniform. During firing, in the case of a bonfire some parts of a pot may be very close to the fire while others may be further apart, creating a temperature difference of as much as $300^{\circ} \mathrm{C}$ within the same vessel. The size and position of the holes on the grate between the fire chamber and stacking chamber are usually even in size as seen in the Miaodigou kilns, the fire holes and fire tunnels usually makes up about $10 \%$ of the entire kiln grate or kiln floor, reducing the amount of fuel needed in updraft-kiln firing. Overall, when a kiln is used, the color and quality of the products will be more uniform.

Furthermore, kilns provide the potter with greater control over firing atmosphere and temperature. By opening or closing the fire door and smoke hole, a more uniform oxidizing or reducing atmosphere can be produced. The structure of the kiln also makes it easier to add fuel and the potter can thus control the strength of the fire more easily. In non-kiln procedures, the control over the atmosphere is weak and as soon as the combustion process has started it is impossible to control the firing atmosphere. It is also difficult to obtain a reducing atmosphere as sealing off the construction completely is largely impossible, and the color of the final products will thus not easily become uniformly gray.

Since kilns have the advantage of allowing for controlling temperature and firing atmosphere, the number of waste products is also greatly reduced and the number of items that can be fired with the same amount of fuel increases, thus improving fuel efficiency.

There are even some more benefits of using a kiln. With the protection of the firing chamber and the stacking chamber, the firing process is not influenced by severe weather such as wind or rain, which is of crucial importance in regions that have long rain seasons. For example, in eastern and southern India and Kashmir, the rain season is eight to nine months long, so complex and simple kilns have become common installations for ceramic production there. In central, northeast, and western India where the rain seasons are short, bonfires are basically the only firing method.

In this way, a comparison of kilns and non-kiln firing arrangements has shown that kiln firing has many advantages such as enhancing control over airflow and firing atmosphere, increasing the firing temperature, increasing fuel efficiency, pottery quality, and avoiding adverse effects of poor weather conditions on the production process. Considering these circumstances, in the overall development of kilns and their popularization, why are there still people who practice non-kiln firing methods and refuse to take advantage of the more advanced technological option?

In fact, kiln-free firing procedures are not without merits, and the advantages of kilns, especially the earliest forms of updraft kilns, are not that great or significant. For instance, kilns can reach temperatures of over $1000{ }^{\circ} \mathrm{C}$ but such temperatures are not necessary for the firing of most of the known prehistoric pottery. Gosselain's research has shown that the temperatures reached by bonfires and simple updraft kilns both range around $600-900{ }^{\circ} \mathrm{C}$ although only the latter sometimes reaches temperatures of $1000{ }^{\circ} \mathrm{C}$. On the other hand, for many types of prehistoric pottery, too high a firing temperature would lead to deformation or cracking of the clay body, and nonkiln firing facilities can achieve the desired temperatures without difficulties, thus fulfilling the requirements of the potters. In fact, for ceramics containing certain types of non-plastic components, higher firing temperatures can reduce the strength of the vessel body. Clay that contains large amounts of limestone fragments or clamshell whose main component is $\mathrm{CaCO}_{3}$, will decompose into $\mathrm{CaO}$ and water when reaching temperatures of $600-800{ }^{\circ} \mathrm{C}$. When 
$\mathrm{CaO}$ and the water in the air combine, they will form $\mathrm{Ca}(\mathrm{OH})_{2}$, leading to the build-up of pressure in the clay body and creating many small depressions in the vessel surface. To avoid this lime spalling, the easiest remedy is to keep the firing temperature with a relatively low range. In kiln-free firing facilities, the pottery can simply be removed before temperatures become too high, and this simple firing method is thus the most suitable one for clay bodies containing limestone or shell fragments.

Additionally, the kiln's ability to preserve heat and thus help with a slow warming and cooling process may not be required. For a fine and dense ceramic body, it is absolutely necessary to maintain a low heating rate, but in the case of coarse ware that contains a large number of non-plastic elements, the structure of the clay body itself is conducive to discharging water vapor and is thus not easily damaged by higher heating rates.

In the case of kiln-free firing, there are many ways in which stains on the product surface can be avoided. For instance, smaller vessels can be placed into larger vessels so that small vessels will not get into direct contact with the fuel. Another option is to remove the ceramics from the fire before they have cooled down and let them cool down in the open air where stains can oxidize out. Also, if the dung of large herbivores is used as fuel, that fuel will be loose and porous and include a lot of oxygen, so it will burn up before ever getting into direct contact with the pottery which will thus not be blackened.

The statement that pottery kilns increase fuel efficiency is also not completely correct as much fuel is needed for heating the kiln itself and some part of the heat created by the fuel will be discharged through the kiln hole.

Furthermore, the greatest advantages of kiln firing the control of temperature and firing atmosphere - are not completely missing from kiln-free firing procedures either. The only difference between kiln and non-kiln firing is the structure itself. By using various types of fuel, timing the firing, and deciding the amount of fuel, the firing process can be controlled to a certain degree, thus directly influencing the firing results. For example, if the initial firing temperature in a kiln-free firing setup was too high, the fuel can be wetted to reduce the increase in temperature; if one wants to extend the time for which a certain temperature is preserved, one can add fuel or choose a specific kind of fuel that slows the combustion process.

Kiln-free firing also has some advantages over kiln firing. First of all, kiln-free firing allows for a free selection of firing sites. Secondly, the costs for constructing and maintaining the firing site are low. In view of these two points, for low-intensity production by small workshops, kiln-free firing methods are ideal. For example, the workshop of San Isidro is the only workshop in southern Veracruz, Mexico, that uses kilns. They also have the highest working intensity by far. When asking a potter during a survey why she did not have her own kiln, she replied that she did not make pottery that often and that it was thus not worth the time and effort to build a kiln.
This matches what archaeologists commonly say about the interplay between the use of kilns and the strength of ceramic products.

In short, when comparing non-kiln firing and kiln firing in terms of their advantages, the latter does not have the absolute advantage, even though the former is the older, less developed technology. Although kiln firing has a number of advantages, when using non-kiln firing methods, an experienced potter still has a number of technical options to make up for the disadvantages of bonfire firing. The decision to construct a ceramic kiln is the outcome of a number of factors including environmental, economic, and social factors. Based on this argument, scholars such as Balkansky argue that the choice of firing technique is not a matter of technological progress with a linear progressive evolution, but that differences in firing technology reflect differences in the potters' technical requirements in terms of kiln structure and desired pottery. Having the pit-firing method in between bonfire firing and updraft-kiln firing is thus a product of pit-firing being right in between the two others in terms of function rather than the outcome of some kind of technological evolution. The question whether the developmental sequence of bonfire firing - clayshell oven firing - vertical-pit firing regularly mentioned by previous scholars can stand and whether - in view of environmental and cultural difference between various regions - development over time has to follow a common sequence, can only be answered through an analysis of archaeological discoveries.

Archaeological evidence for kiln-free firing technology

For a long time, evidence for non-kiln firing technology was available only through ethnoarchaeological observations while archaeological evidence was absent. This is because kiln structures are durable, distinctive in appearance, preserve easily, and are easy to identify. Nonkiln firing facilities are not like this, with bonfires not leaving any marked traces and firing pits not leaving any clear traces that would distinguish them from other kinds of archaeological features. An even greater problem is that our knowledge of kiln-free firing methods is insufficient such as the range of types, firing methods, firing process, and diagnostic products, as well as an understanding of what kind of archaeological remains such a firing procedure would leave behind.

First of all, some types of kiln-free firing leave behind visible traces, but we need to learn how to identify them. It is easier to identify the remains of clay-shell ovens in pits. Based on analogies with firing experiments and their comparison with archaeological finds, large numbers of potsherds, gray ash layers mixed with charcoal, redburnt clay on the walls and bottom of pits, fragments of fired clay shells, and other finds connected with ceramic production, it can be shown that clay-shell oven firing inside a pit took place; however, the material traces of non-kiln firing techniques on the surface that did not use a clay shell will vanish after a time, and its remains will not look any different than those of an ordinary hearth, 
making identification particularly difficult.

Secondly, the firing products, i.e., certain characteristics of ceramics, can be used as indicators for identifying nonkiln firing processes. For instance, the firing products will have been in direct contact with fuel and flames, so their surface will often display stains and a mottled color. As the clay body needs to withstand large temperature changes, the clay matrix needs to contain large amounts of non-plastic components so that there is enough space for water to be discharged, so the presence of cracks and firing defects can be used as supplementary evidence to identify non-kiln firing procedures.

In previous research, the identification of kiln-free firing procedures has largely been the result of a process of exclusion. In other words, if ceramics were unearthed from a site that did not reveal a pottery kiln of the same period, while the date of this site is rather early, it has been generally assumed that people at this location and time used kiln-free firing techniques. Some excavators are indeed very aware of the particular traces that this kind of firing would leave and they make detailed records aiming to identify bonfire locations. Some scholars have taken inspiration from ethnoarchaeological research on kiln-free firing techniques and provide detailed records of related evidence in their excavation reports, and some of them have indeed found indicators for kiln-free firing. The indicators are burnt-soil layers, large piles of plant ash, charcoal, and baked earth. These remains can be divided into two categories, heaps of red-baked earth (or red-backed soil surfaces) and red-baked earthen pits, and they have been discovered at Nanzhuangtou 南庄 头 Site in Xushui County, Hebei, Egou Beigang 莪沟
北岗 Site in Mixian County (present-day Xinmi City), Henan, Baijiacun 白家村 Site in Lintong, Shaanxi, Jiahu 贾湖 Site in Wuyang, Henan, Shang Jifangyingzi 上 机房营子 Site in Chifeng, Inner Mongolia, Liulin 刘 林 Site in Pixian County, Jiangsu, Songze 崧泽 Site in Qingpu, Shanghai, Hutoupu 虎头埔 Site in Puning, Guangdong, Tanshishan 县石山 Site in Minhou, Fujian, and Fuxikou 涪溪口 Site in Wanzhou, Chongqing (see Table 1). In terms of the identification of these remains, most researchers and excavators called them "ceramicproduction methods prior to the emergence of kilns" or "bonfire remains", but they seldom specify them any further in terms of sub-categories.

After a closer review at the excavation reports, the author of this paper noticed that many of the features listed in Table 1 contained piles of baked-earth clods; among them, the red-baked earth of Baijiacun Site in Lintong is the most interesting. Here, there were large amounts of baked earth "that on their underside were indented and uneven in colors ranging from brick-red to purplish-brown, while the upper side was rather flat and pale gray in color. The uneven side showed plant impressions in many places." These baked earth clods may be remains of the clay shell of clay-shell ovens, the lower, uneven side being the side pressed onto the firewood and thus naturally showing plant impressions. The detailed description of the baked earth clods by the excavators allows us to make a daring speculation and suggest the use of a specific firing method, very likely a clay-shell oven erected directly on the ground surface.

Based on the material that is currently available from the Neolithic to the Bronze Ages in China only non-kiln

Table 1 Features related to kiln-free pottery firing.

\begin{tabular}{|c|c|c|c|c|c|}
\hline Site & Feature type & Number & Plan & Date & Deposition and artifacts \\
\hline Nanzhuangtou & Heap of red-baked earth & 2 & Circular & Early Neolithic Age & Potsherds \\
\hline Egou Beigang & $\begin{array}{l}\text { Red-baked ground } \\
\text { surface and pit }\end{array}$ & 1 & Quasi-circular & $\begin{array}{l}\text { Mid Neolithic Age } \\
\text { (Peiligang Culture) }\end{array}$ & Plant ash, potsherds \\
\hline Baijiacun & Heap of red-baked earth & 1 & Irregular circular & $\begin{array}{l}\text { Mid Neolithic Age } \\
\text { (Dadiwan Culture) }\end{array}$ & Potsherds, baked earth clods \\
\hline Jiahu & Red-baked pit & 7 & Circular or Oval & $\begin{array}{l}\text { Mid Neolithic Age } \\
\text { (Peiligang Culture) }\end{array}$ & Baked earth clods, plant ash \\
\hline $\begin{array}{l}\text { Shang } \\
\text { Jifangyingzi }\end{array}$ & Bag-shaped pit & N/A & N/A & $\begin{array}{l}\text { Bronze Age (Upper } \\
\text { Xiajiadian Culture) }\end{array}$ & $\begin{array}{l}\text { Baked earth clods, charcoal } \\
\text { debris, white ash, potsherds }\end{array}$ \\
\hline Liulin & $\begin{array}{l}\text { Red-baked ground } \\
\text { surface }\end{array}$ & 1 & N/A & $\begin{array}{l}\text { Late Neolithic Age } \\
\text { (Dawenkou Culture) }\end{array}$ & Charcoal debris, potsherds \\
\hline Songze & $\begin{array}{l}\text { Red-baked ground } \\
\text { surface }\end{array}$ & 4 & Irregular & $\begin{array}{l}\text { Late Neolithic Age } \\
\text { (Songze Culture) }\end{array}$ & Charcoal ash, potsherds \\
\hline Hutoupu & Open-air firing pit & 6 & $\begin{array}{l}\text { Rectangular, } \\
\text { square, circular, }\end{array}$ & Final Neolithic Age & $\begin{array}{l}\text { Potsherds, Charcoal debris, } \\
\text { plant ash }\end{array}$ \\
\hline Tanshishan & $\begin{array}{l}\text { Red-baked ground } \\
\text { surface }\end{array}$ & 1 & N/A & $\begin{array}{l}\text { Final Neolithic Age } \\
\text { (Tanshishan Culture) }\end{array}$ & Heap of potsherds \\
\hline Fuxikou & Red-baked pit & 1 & Rectangular & Xia Dynasty & N/A \\
\hline
\end{tabular}


firing techniques were used that included at least the three types of bonfires (Nanzhuangtou, Liulin and Songze), clay-shell ovens erected directly on the surface (Baijiacun), and pit firing (Hutoupu and Fuxikou). Chronologically speaking, in the north, the period of non-kiln firing extended from the early to the middle Neolithic Age while in the south is extended throughout the late and end Neolithic to the early Bronze Ages.

Several scholars have already pointed out the unevenness in kiln development between north and south, pointing out that when the people living north of the Yellow River already widely used ceramic kilns, among groups in the south, due to the high water table and the mountainous geography, updraft kilns could be used only in the late Neolithic Age. Referring to archaeological data and ethnographic information, it has become clear that the high water table, the heavy rainfall, and other local geographic particularities pushed the development of firing technologies in north and south further down very different routes. The north shows a sequence of "bonfire - single-use clay-shell oven - round-pit updraft kiln horizontal-draft kiln - horseshoe-shaped kiln - downdraft kiln" while in the south ceramic firing technology developed from "bonfire - surface-level single-use clayshell oven - unclear form - northern phase 4 updraft kiln and southern-style surface-level dragon kiln - halfdowndraft corridor chamber-style kiln."

Unfortunately, previous researches have not been fully aware of the large variety of possible forms of kilnfree firing and their particularities, leading to the current situation of a lack of material making it impossible to discuss in greater detail kiln-free firing technology and its developmental history. From the exemplary material listed above it also becomes clear that it is not enough to simply point out the differences in the developmental routes of firing technology between north and south. For instance, although the Hongshan Culture in the Xiliao River area already has an advanced kiln technology, until the Bronze Age bonfire firing is still continued to be used. Do kilnfree firing methods still continue in the north even after the invention of the pottery kiln? After all, kiln-free firing methods have their advantages. Furthermore, seen from the point of view of a group of people or a settlement, pottery technology is a choice and this choice needs to fit with the environmental, social, and cultural makeup of the time and the place in question. However, limited by the insufficient relevant material, it is difficult to discuss this question in greater detail.

In order to fully explain non-kiln firing technologies and their significance, during future surveys and excavations, we have to pay particular attention to potential remains of kiln-free firing process such as redbaked earth, burnt surfaces, charcoal, and potsherds. At the same time, we also have to be careful to distinguish between the traces of non-kiln firing process and remains left by other activities such as wattle-and-daub walls, alcohol production facilities, hearths, and the like. Furthermore, the products of these firing techniques, the potsherds themselves, and their characteristics can be used to infer on firing technology.

Discussion on theories of ceramic technology development: choice or evolution?

Looking at the question posed at the beginning of this paper (why is it that even today some people still use kilnfree firing methods to produce their ceramics), we can now answer: this is an outcome of differences in natural environment and cultural traditions, leading to an uneven development of firing technology in different regions and different routes of development.

At this point, this question does not have a perfect answer, yet. Even if there were different routes of development, would they not all lead to an increasingly better, more advanced method? For many scholars, the answer is self-evident as they believe that technology must move forward advancing to increasingly more perfect methods, although that does not mean that there is only one possible evolutionary path. However, there are also scholars who hold that this believe in a continued advancement of technological development confuses technological development and technological advancement which are two different things.

The confrontation between these two opposing views is one of the manifestations of the debate between cultural evolution and postmodernism as two schools of thought emerging in archaeology in the 1980s. The theory of technological advancement comprises three main points: technological change is always progress toward a better and more effective solution of a technological problem, and the solution is rooted in scientific facts. This theory of technological advancement of human culture has been the dominant school of thought in European and American higher-level research from the 1960s to the 1980s. In ceramic research, this progress theory manifests itself mainly in two aspects, one being that pottery technology progresses over time, that is, the concept of technological evolution, including the model of a developmental sequence from bonfire to updraft kiln mentioned in this paper; the other being that the complexity of ceramic production techniques develops with the increase in level of social complexity of the group in question.

In the 1980s and 1990s, European sociologists and anthropologists reflected in great depth on the theory of technological change. Among them, Lemmonier's theory of technological choice has been particularly influential. In the latter part of the 1980s, some European archaeological schools were strongly influenced by postmodernist ideas and began to criticize previous theoretical ideas on the inevitable improvement of ceramic technology over time through the study of example from modern history and ethnography. Among them, the Leiden School led by Van der Leeuw has been most influential and most widely read. The Leiden School advocates breaking with the idea of finding one unified pattern of development and instead emphasize situational research, holding that the local situation, general human behavioral diversity, and its interaction with historical events shaped local handicraft. 
This school conducted much research on the idea of traditional "ceramic technology progressing naturally over time", and they have also emphasized the complexity of pottery production and its connection with social complexity.

In the Americas, the influence of progressivist views on ceramic production and its development continued to exert a great influence into the 21 st century. Chinese scholars are very familiar with the work of the pottery expert Prudence Rice who is an active advocate of this idea. She holds that the rise of social complexity and changes in ceramic production are connected, arguing that ceramic production naturally will lead to an increase in social complexity, with an increase in pottery standardization leading to increasingly complex structures. Cathy Lynne Costin has conducted an in-depth study of models of evolutions of handicraft production. Anne Underhill tried to apply on of her models to Chinese archaeological material. Until the 21st century, many young American scholars were strongly influenced by the Leiden School of thought; since then, in the field of pottery technology research, the drive to search for a common law or model of development gradually faded and researchers began to conduct in-depth local studies instead.

So, between inevitable evolutionary progress and technological choice, which model is correct and which false? For this argument, there may be no clear answer. Similar to Trigger's classic analogy, as neither can be proven or falsified, neither of those theories can be called correct or false, and they stand as two religions of which we may choose to believe only in one. Both theories are excellently argued; in matters of long-term development of ceramic technology and production, the progressivist approach is able to cover larger supra-regional changes; when wanting to analyze a specific site and its pottery technology and production, it may be more appropriate to use the postmodernist approach of local particularism.

In Chinese archaeology, research on pottery technology and production started rather late and at present related studies are few, all of them having been influenced by evolutionary models proposed by Rice, Costin, Underhill, and other American scholars. In research on technology, when talking about technological change, the focus is usually on improvements in vessel functions and technology, while discussions on changes in mode of production usually start from handicraft production models. Although international academic exchange has increased, most scholars in China still mainly focus on the theories of the Leiden School, while postmodernist ideas emerging from idealist ontologies are not easy to understand and not compatible with theoretical approaches of Chinese scholars. It cannot be denied that ancient Chinese civilization has its own unique particularities, and through in-depth research on early pottery technology and production processes we may discover that models of technological development established by western scholars may not be fitting for the Chinese case. Furthermore, when dogmatically adhering to ideas of technological progress, technological change becomes a necessity, but the background and reasons behind these changes are easily overlooked.

In future research, when discussing the significant technological inventions such as the ceramic kiln and the potter's wheel, we may want to consider the matter from the point of view of technological choice instead of simply attributing such changes to requirements of society progress, thus including aspects such as then natural environment, cultural traditions, and other factors. When discussing modes of ceramic production, seen from a post-processual point of view, we may not have to remain confined to rigid models of production.

\section{References}

Gosselain, O. P. 1992. Bonfire of the enquiries. Pottery firing temperatures in archaeology: What for? Journal of archaeological science 19(3):243-59.

Gosselain, O. P. and Smith, A. Livingstone. 1995. The ceramics and society project: an ethnographic and experimental approach to technological choices. In Lindahl, A, and Stilborg, O.[eds]. The aim of laboratory analyses of ceramics in archaeology, April 7-9, 1995 in Lund Sweden. Stockholm: Kungl. Vitterhets historie och antikvitets akademien. pp. 147-60.

Li, Yangsong 李仰松. 1958. 云南省佤族制陶概况 (The survey of the pottery-making of the Va people in Yunnan Province). Kaogu tongxun 考古通讯 (Archaeology newsletter) 2:32-40.

Lin, Sheng 林声. 1965. 云南傣族制陶术调查 (Survey on the pottery-making technique of the Dai people in Yunnan). Kaogu 考古 (Archaeology) 12:645-53.

Qimed Doje 古格. 齐美多吉. 1999. 西藏地区土陶器产业 的分布和工艺研究 (Distribution of the Tibetan pottery industry and its technological study). Xizang yanjiu 西藏 研究 (Tibetan studies) 4:25-37.

Smith, Livingstone A. 2001. Bonfire II: the return of pottery firing temperatures. Journal of archaeological science 28(9):991-1003.

Wang, Ningsheng 汪宁生. 2003. 云南傣族制陶的民族考 古学研究 (An ethnoarchaeological study on the potterymaking of the Dai people in Yunnan). Kaogu xuebao 考古 学报 (Acta Archaeologica Sinica) 2:241-62.

Yang, Li 杨莉. 2002. 云南民间制陶技术的调查研究 (An inquiry into folk ceramics technology in Yunnan Province). Zhongyang minzu daxue xuebao. Zhexue shehuikexue ban 中央民族大学学报. 哲学社会科学版 [Journal of Minzu University of China (Philosophy and social sciences edition)] 3:35-9.

\section{Postscript}

The original paper published in Kaogu 考古 (Archaeology) 2016.3:74-85 with three illustrations and one table is authored by Meng Guo 郭梦. This abridged version is prepared by the author and translated into English by Anke Hein 安可. 